\title{
"Politics for Girls": Representations of Political Girlhood in the Girl's Own Paper and
}

\section{the Girl's Realm}

\section{HELEN SUNDERLAND}

In January 1899, the Girl's Realm, a sixpenny monthly girls' periodical launched the previous autumn, included a short story titled "Queen Mab" about a group of siblings who ran their own parliament. In their political play, the children mimic parliamentary procedures with considerable detail. Each sibling is elected as a Member of Parliament and debates are conducted with the correct "parliamentary language," all overseen by ten-year-old Patience, the organizer of the proceedings, and fourteen-year-old Albinia, who acts as Speaker. ${ }^{1}$ The author of the story, Emma Marshall, was a prolific children's writer as well as a promoter of women's education and suffrage. Her story points to a wider phenomenon of girls' periodicals engaging with political themes.

Both fiction and non-fiction articles in the Girl's Realm and the Girl's Own Paper at times explored the idea of juvenile, and specifically girlhood, citizenship; in doing so, they constructed the girl reader as an imperial and political subject. As Marshall's "Queen Mab" story exemplifies, understandings of girls' politics in the period were complex. Patience's appropriation of political language is in part attributed to the influence of her father, a member of the division of the county. This highlights the perceived importance of the family as a site for girls' political socialization and raises the question of how far girls' engagement with politics was understood to be adult-directed. Patience is represented as an exception rather than the norm. Her level of political interest is presented as unusual for a girl of her age, and she is mocked for being "too much like a 'grown-up.",2 Indeed, her younger brother and sister are often reluctant to comply with the parliament's rules, while her cousin Mabel rejects the institution entirely. In this way, the Girl's Realm engaged with a key debate in 
contemporary political culture: how far political maturity and participation were determined by age and gender.

Sally Mitchell's seminal work on the "new girl” identified a cultural transformation in girlhood between 1880 and 1915. This model of new-found female independence, though separate from the lived reality of girlhood, was hugely influential in shaping contemporary literary and cultural ideals. ${ }^{3}$ Scholarship on the "new girl" has, however, overlooked an important dimension: political girlhood. Indeed, in a 1903 article in the Girl's Own Paper tracing the changes to girlhood over the previous fifty years, Lily Watson not only noted the emergence of the "Bachelor Girl" and "Professional Girl" but also took notice of the "Political Girl.". Much had changed, she commented, since the time when the "Political Girl was nowhere to be found at all." 5

This essay argues that the fin de siècle girls' periodical press played an important role in constructing narratives of girls' engagement with empire and parliamentary politics. It draws primarily on the two most successful girls' periodicals of the period: the penny weekly Girl's Own Paper, launched in 1880 by the Religious Tract Society, and the Girl's Realm, first published in 1898. Both periodicals have received considerable attention in recent scholarship; however, the periodicals' construction of girls' imperial and political identities has yet to be analyzed fully. ${ }^{6}$ The existing scholarship has overlooked the place of parliamentary politics within girls' periodicals, especially the Girl's Own Paper. My analysis will suggest that periodical literature provided a forum for debate about the politicizing influences of the family and school. Indeed, girls' periodicals also acted as sites for girl readers' implicit and deliberate political education through fiction and non-fiction articles as well as correspondence pages, which offered a platform for readers to experiment with partybased political expression and further their understanding of the political system. 
Sociologists and geographers of childhood have called for a greater appreciation of how politics informs children's daily lives. ${ }^{7}$ By giving closer attention to instances of imperially and politically themed play within the periodicals, this essay points to a more ageinclusive and accessible means by which public discourse could form part of readers' everyday experiences. I also consider how girls adopted imperial and political narratives, thereby engaging in the "appropriation, reinvention, and reproduction" central to juvenile political socialization. ${ }^{8}$ Through contributions to both periodicals, girl readers demonstrated how they might incorporate political ideas within their own peer cultures. Literary examples of such politically engaged girls further suggest that political girlhood was a model with which adult authors could experiment. Editors, authors, and readers alike thus constructed shifting and varied patterns of politicized girlhood in the turn-of-the-century periodical press.

An analysis of periodical literature inevitably raises the challenge of uncovering reader experience. Gretchen Galbraith highlights how late Victorian and Edwardian concerns about children's literature stemmed from an understanding of reading as consumption- the notion that children are what they read. ${ }^{9}$ We must caution against drawing similarly simplistic conclusions. Margaret Beetham's influential study of women's magazines in the long nineteenth century suggests how the nature of the periodical form created the potential for readers' autonomous and subversive engagement with the text. ${ }^{10}$ The readership of gendered periodicals was never fixed: girls read magazines directed at boys and vice versa. ${ }^{11}$ More recently, Beth Rodgers has highlighted the "extent to which newspapers and magazines helped to bring the modern girl into being through articles, stories and the platform they gave to girls to contribute to such debates."12 This twofold approach, incorporating periodical content and reader contribution, is helpful. I will therefore focus not just on the forms of politicized girlhood that periodicals presented to their readers but also how readers themselves contributed to these narratives. The analysis first nuances existing understandings 
of imperial girlhood presented in girls' periodicals through a new focus on girls' appropriation of imperial discourse in their language and recreation. It then turns to an area neglected in the existing scholarship: how the periodical press was a site for girls' engagement with parliamentary politics.

\section{"A Daughter of the Empire": The Girl Reader as Imperial Subject}

Countering the overwhelming scholarly attention given to empire in boys' literature, Kristine Moruzi and Michelle Smith identify the central role of the periodical press in constructing narratives of imperial girlhood. Imperial fiction, they helpfully argue, demonstrated girls' expanded sphere of action. The colonial setting legitimated female independence, selfsufficiency, and bravery, albeit still within a gendered framework. ${ }^{13}$ These analyses are, however, problematic in their prioritization of periodical content over reader reception. Focusing instead on the interaction between author, editor, and reader, this analysis seeks to demonstrate not only how periodical literature constructed the girl reader as imperial subject but also how it encouraged her active participation in the colonizing mission.

The elision of imperial struggle and female heroism is particularly striking in the historiography of empire in girls' periodicals. Moruzi argues that the Girl's Realm "[adapted] its ideal of modern, heroic girlhood to address the ramifications" of the Second Boer War. ${ }^{14}$ While her study encompasses heroism on the home front through charitable contributions to the war effort, Moruzi's conceptual focus on heroism risks reinforcing the distance between imperial adventure and readers' lived experiences. Heroic girlhood was unlikely to be within the reach of all readers. Heroism was, moreover, only one type of imperial girlhood the periodical celebrated. When we consider how girls' periodicals depicted girls' literary and lived appropriation of imperial themes in their language and play, empire emerges as a more immediate and accessible part of girls' everyday lives. 
The Second Boer War (1899-1902) provided a focus for girls' engagement with empire at the turn of the twentieth century. Girls' periodicals often encouraged this interaction. The Girl's Realm, in particular, expected a considerable level of imperial interest from its readers. In her monthly column "Chat with the Girl of the Period" in January 1900, editor Alice Corkran recommended a book about a girls' school in Cape Colony, addressing readers "who are thinking of the Transvaal—and I am sure that all your hearts are on the battlefield there." 15 Two months later, another article on the contributions of British girls' schools to war charities reiterated this message. "There can scarcely be a girl in Great Britain to-day whose every thought is not turned to South Africa," the author declared. ${ }^{16}$ Implicit in these assertions was the representation of an ideal: that girls should be invested, heart and mind, in the imperial cause.

Girls were also urged to participate in more practical ways. Readers of the Girl's Realm were asked to send hand-knitted socks and other items to soldiers at the front. ${ }^{17}$ Both the Girl's Own Paper and the Girl's Realm answered numerous questions from readers about sending parcels to soldiers and toys for their children. ${ }^{18}$ This perhaps indicates readers' unsolicited engagement with the war effort, though editorial influence in the production of correspondence pages makes it impossible to determine their authenticity. Similarly suggesting readers' autonomous engagement with the war effort, in a competition where entrants were asked how they would spend $£ 1,000$, donations were pledged to "funds for the benefit of our brave troops fighting in South Africa." ${ }^{19}$ In this case, readers' participation in the war effort remained within accepted gender boundaries, emphasizing philanthropic and domestic work. Indeed, Moruzi argues that imperial contributions that were deemed suitable for girls "remain distinctly feminine." ${ }^{20}$ Nevertheless, girls' periodicals placed value on readers' material support for the imperial cause by explicitly encouraging their efforts, reporting on girls' supposedly unprompted engagement with the war, and elevating such 
examples into an ideal worthy of emulation. Editors appeared keen to impress on their girl readers that female support for the empire was not limited to adults or the colonial setting but was something in which they could meaningfully participate.

Correspondence pages are an important source for readers' interactions with periodicals and can help deepen this analysis of girls' imperial action. Several entries in the Girl's Own Paper evidence how readers might engage spontaneously with imperial themes. During the Boer War, some correspondents adopted war-themed pseudonyms, such as "Tommy Atkins," "Khaki," "Mafeking," and "Pro Patria," suggesting how correspondence pages could provide a platform for patriotic self-expression. ${ }^{21}$ It is notable that these patriotic and military terms were permitted in a periodical that claimed to be apolitical in character. Although it has been shown that boys sometimes read girls' periodicals, one might speculate that the first example could be a girl reader adopting the persona of a British soldier. The fact that the editor published an answer to "Tommy Atkins" at all suggests that such personal identification with the war would not have seemed inappropriate for a girl. Clarification on how to pronounce khaki aside, the questions that followed were unrelated to the war. Rather than suggesting girls' disengagement with the conflict, this arguably demonstrates the extent to which the war had become a normal part of life. Readers could invoke military and patriotic discourse without the need for further contextualization. Through a simple phrase easily recognizable to the editor and other readers, they celebrated their nation, its soldiers, and victories.

Readers also displayed more sustained patriotism in other contributions to these periodicals. Even young girls were able to engage with ideas of nation and empire in this way. In 1901, Ethel Matheson wrote to the Girl's Realm's “Children's Own Corner" (for children aged ten or younger) with a poem she had composed to General Buller, suggesting that she felt a personal connection to the Boer War general. ${ }^{22}$ Girls therefore not only 
engaged with empire through prominent female figures, such as Queen Victoria or imperial heroines, but could equally do so through male military figures. ${ }^{23}$ The Girl's Own Paper was more critical of its readers' literary efforts, praising contributions more often for their sentiment than literary merit. One contributor was criticized for the "rather eccentric" meter and questionable syntax of her poem, "Stand by the Flag of England." 24 She received a mixed response: "we cannot praise your work" but "applaud your patriotism." 25 Other submissions included a song entitled “The Garden of Britain,” inspired by Lord Meath’s 1904 Empire Day speech on national flowers, and a poem that gave a "good description of the public emotion at the close of the South African War." ${ }^{26}$ Where literary quality was found wanting, patriotic enthusiasm could be more readily praised. In choosing to acknowledge these patriotic submissions, periodical editors demonstrated their support for readers' use of nationalistimperialist narratives and implicitly welcomed similar contributions.

Such imperially themed contributions were more deliberately encouraged by the Girl's Realm during the Second Boer War. In July 1900, a writing competition for "an original adventure story" awarded prizes for stories "inspired" by "the present war." 27 While usually preferring not to publish correspondence in full, the Girl's Realm printed letters from readers in South Africa about British victories in late 1900, suggesting the significance of girls' direct experiences in the colonies. ${ }^{28}$ The periodical thus cultivated an image of the ideal reader educated in imperial ideas and expressing unprompted loyalty to nation and empire. Furthermore, by publishing these patriotic contributions, the editor encouraged girl readers to engage with empire through the experiences of their peers at home and overseas. This reveals an important reader-driven dimension to how girls' periodicals, as Beth Rodgers has demonstrated, aimed to construct an "idealised, inclusive community of girl readers" across the empire. ${ }^{29}$ 
The Girl's Realm also encouraged imperial self-education more explicitly. The regular "Literary Page," which invited readers to submit essays on a selected text, was often given over to imperial themes at the turn of the century. In May 1899, the column urged readers to study Rudyard Kipling's A Fleet in Being, explaining its imperialist message. ${ }^{30}$ Readers' essays on the book, separated into two categories over and under the age of sixteen, were praised for their patriotism; the editor noted that "pride in our Navy is the animating spirit of all these essays." 31 The following year, J. R. Seeley's The Expansion of England was met with less enthusiasm by readers. Prizes were awarded to twenty-three-year-old Daisy Pocock and nineteen-year-old Florence Norman, who, we are told, tackled the subject from the Conservative and Liberal perspectives. It is interesting, and unusual, that party political opinions are mentioned here. This instance suggests that engaging with empire allowed girls an opportunity to express more partisan political ideologies, though the fact that opposing party lines were both featured was perhaps a deliberate attempt to demonstrate the Girl's Realm's political impartiality. Editor Alice Corkran lamented that more readers had not taken part. "I have been a little disappointed in the number of Essays sent up to me by the members of The Girl's Realm Reading Union on 'The Expansion of England,'” she wrote. ${ }^{32}$ She framed it as a missed opportunity for girls to expand their appreciation of imperial history: "It was a great subject for thoughtful girls to master, for at this critical point in our history, when our compact little island is transforming itself into a mighty Empire, it behoves the younger generation, in whose hands its mighty destinies are so largely placed, to understand the duties and obligations their country is undertaking." ${ }^{33}$ Girls needed to know about the empire, Corkran argued, because they had an important role to play in shaping the imperial future. Her reference to "the younger generation" perhaps aimed to encourage younger readers to participate in future competitions. 
Didactic approaches evidently had their limits in generating girls' imperial interest. Elsewhere, the periodicals suggest younger girls' more autonomous engagement with empire through play. ${ }^{34}$ Several works of fiction in the Girl's Realm depict nationalist-imperialist themes in girlhood play. In "Our Neighbour Over the Way" and "How De Wet was Captured," children appropriate the language of war in their peer cultures, either discussing the latest events in the conflict or enacting them. ${ }^{35}$ With the latter, children are shown to mimic the same imperial heroism that Moruzi has identified elsewhere in the Girl's Realm. As such, imperial adventure might have appeared more accessible for girl readers. Indeed, another short story in 1907 followed a group of siblings who, inspired by the Plaistow Land Grabbers' occupation of wasteland in protest of unemployment the previous year, claimed a plot of their neighbor's land. With echoes of Patience's leadership of the sibling parliament in "Queen Mab," this "land-grabbing" is directed by a young girl. ${ }^{36}$ Twelve-year-old Maudie invokes political justifications for the group's actions, leading a "council" to determine the way forward and agreeing that an "Act of Parliament" would be needed to make them surrender the newly captured land. ${ }^{37}$ There seem to be colonial undertones to the children's exploration and capture of this forbidden territory. Again, girls' imperial and political interests go hand in hand. The authors of both stories use children's imaginary play to demonstrate preadolescent girls' political and imperial agency. These examples nuance Rodgers's argument that the Girl's Realm “consistently encouraged its readers to think beyond the confines of domesticity." ${ }^{38}$ Certainly, the periodical celebrated girls' public achievements, but we should not overlook how the domestic space itself acted as a site for young female political expression.

Girls' imperially themed play was not limited to fiction. Both the Girl's Realm and the Girl's Own Paper encouraged readers to incorporate empire more directly within their own recreation. In January 1901, the Girl's Realm gave instructions for making a hand 
shadow of "Oom Paul"-Paul Kruger, the former President of the South African Republic and a prominent figure in the Boer War. ${ }^{39}$ As the article's title shows, this was promoted as part of a "drawing-room entertainment," indicating that girls' imitation of Kruger was supposedly for adults' amusement. The fact that most of the hand shadow instructions were of animals makes the inclusion of Kruger even more incongruous. Four years later, the Girl's Own Paper taught readers how to create images of British soldiers and the Union Jack using a typewriter. ${ }^{40}$ An advertisement for "Everybody's War Game" in the March 1900 issue of the Girl's Realm, described as "a capital game for girls, or an excellent present for their brothers," highlights how the more commercial elements of the periodical encouraged girls to engage with empire alongside their male peers. ${ }^{41}$ Collapsing the boundaries between imperial education and play, the game is described as "a thrilling and instructive amusement." ${ }^{, 2}$ While many girls were interested in the war, another article promoting the game suggests that their geographical knowledge of the conflict was less developed. The game would remedy this by providing a detailed map of South Africa: "this capital war game will teach them sooner than a geographical lecture could do."43

Imperial play in much of the periodical did, however, remain gendered. In the Girl's Realm for June 1900, a series of comic photographs of a young girl dressed in colonial uniform suggests that editors expected the Boer War to form part of girls' play. By including an image of "A Daughter of the Empire" toasting the queen at a tea party with toy soldiers, the piece at once legitimizes girls' playful appropriation of empire and restricts it within accepted gendered boundaries. ${ }^{44}$ Capitalizing on the contemporary craze for pageantry, an article commemorating Mafeking Day shows how "one little girl was filled with an interesting desire to "do something' to commemorate so great an occasion." ${ }^{45}$ In a series of tableaux vivants using her doll collection, the girl celebrates "Patriotism in Doll Land." The grand finale, "Rule Britannia," is accompanied by patriotic music and features dolls in 
colonial dress surrounding a larger doll dressed as Britannia. ${ }^{46}$ A number of other articles offer imperially themed fancy dress ideas, including "The New Britannia" and "The All-Red Trade Route." ${ }^{47}$ Evoking Britannia, the Girls' Realm showed girl readers how they too might embody their commitment to nation and empire.

How should we interpret this imperial play? Was it any less valid than adult enthusiasm for empire? Kathryn Gleadle's study of English boys' imitations of community rituals celebrating the 1814 peace treaty can help to unpack these interpretive challenges. Juvenile play should not be seen, she argues, as a passive reflection of adult reality. Instead, children's conscious reinterpretation of the world around them can reveal insights beyond their own play: "Analysing the imitative loyalist actions of children can be a tool with which to enrich our understandings of the constitution and performance of patriotic identities." $" 48$ Similarly, the examples of imperial play in the Girls' Realm and Girl's Own Paper have an added layer of adult editorial influence. The emphasis on fancy dress, pageantry, and performance in these imperial recreations indicates that such activity was directed outwards. Girls' imperial play was a spectacle, intended perhaps for the entertainment of adults around them. But while this could be seen to undermine their agency-evidence of the amusing novelty of young girls' imperial precocity-I would argue that it demonstrates their ability to engage with the dominant imperial narratives of the day. As contributors to imperial discourse, girls were claiming their place as imperial subjects.

Girls' imperial recreation remained constrained by age. In their imperial play, age appears simultaneously empowering and disempowering. Whereas Mitchell has presented the "new girl" as enjoying a "provisional free space" between childhood and marriage, here it is preadolescence that affords the most freedom for girls' imperial appropriation. ${ }^{49}$ Girls' autonomous engagement with empire is sanctioned only when it appears least threatening and can be dismissed as child's play. By encouraging this patriotic play, girls' periodicals 
therefore celebrated a specifically young girl imperial subject. For preadolescent girls at least, imperial engagement was normalized, expected, and encouraged.

This analysis has suggested how girl readers contributed to the construction of imperial girlhood in the periodical press. The Girl's Realm especially valued the imperial loyalty of its readers, who were encouraged to give emotional and material support for imperial causes during the Second Boer War. Girls' engagement with empire was not, however, always led by adults; readers' correspondence and submissions to literary pages suggest that girls sometimes initiated these imperial efforts. The image of the ideal girl reader autonomously expressing imperial patriotism was, indeed, one that editors sought to cultivate. Despite the existing scholarship's focus on imperial heroism and colonial adventure, girls' periodicals also showed readers how they might appropriate imperial themes in their peer cultures, language, and play. As such, empire formed a more immediate part of their everyday lives and was also accessible to young girls. Both in fiction and real life, preadolescent girls in particular were given freedom to express their imperial identities within the home.

\section{"Tories in Tailor-Made Frocks," "Liberals in Lace," and "Socialists in Short Petticoats": Girls and Parliamentary Politics}

The late nineteenth-century press featured considerable debate about girls' exposure to political ideas in the schoolroom. Writers disagreed about girls' capacity to understand politics and whether their political knowledge should be developed or restrained. The Journal of the Women's Education Union, first published in 1873, referred on several occasions to the question of political content in history taught to girls. The politicizing potential of the history curriculum, which could encourage pupils to develop civic, national, and imperial loyalties, has long been recognized in the historiography. ${ }^{50}$ In 1875 , the journal's editor and prominent women's education campaigner Emily Shirreff justified the subject's place in girls' education 
by emphasizing its moral rather than political purpose. History's "political lessons are," she argued, "beyond the mental stature of children." 51 This may have accurately reflected editorial convictions. Or it could be, as Ellen Jordan argues, a strategy deployed by educational reformers to frame their arguments for expanding the female curriculum with more conservative gendered ideals. ${ }^{52}$ In downplaying the political nature of history teaching, Shirreff appears keen to respond to contemporary concerns about girls' exposure to politics in the classroom. The following year, the journal advertised a series of lectures for teachers delivered by James Bryce, the former Chairman of the Royal Commission on Secondary Education and later Liberal MP. The inclusion of subjects such as the "Treatment of Political or Constitutional History" and "How to Deal with Current Politics" further suggests that the handling of political questions in girls' history teaching needed to be carefully negotiated. ${ }^{53}$ Such debates continued into the twentieth century, with both the Historical Association and the Third Annual Conference of the National Federation of Women Teachers discussing the matter as late as 1912, more explicitly within the context of agitation for women's suffrage. ${ }^{54}$

Girls' exposure to politics in the schoolroom did not, however, remain a matter of abstract debate. The press on occasion mobilized "real-life" examples of schoolchildren's political socialization. In 1873, the Times noted with interest how the Rev. G. Steele, Inspector of Schools in Lancashire, incorporated tests of political knowledge into his inspections by asking pupils to read the day's newspaper aloud before questioning their understanding of "such persons as Mr. Gladstone, Mr. Disraeli, Mr. Forster, M. Thiers" and the royal family. ${ }^{55}$ Juvenile political understanding was thus expected to stretch to key political figures. This was presented as a novel and effective examination method; however, with the details of a Lancashire inspector being reported in a London newspaper, it suggests Steele's methods were the exception rather than the norm. 
In the Girl's Own Paper's 1890-91 series "Some Types of Girlhood," the school is presented as a key site for young women's political action. In these articles, "political girlhood" appears alongside other forms of young female spinsterhood: muscular, literary, musical, artistic, medical, religious, and aesthetic. ${ }^{56}$ The boundaries of girls' accepted political actions are, however, relatively constrained. While learning that "politics are by no means outside a woman's sphere of influence," readers are shown only one place for women to exercise their politics: the classroom. The author, Sophia Caulfield, asserted that as teachers, women have a key role in instilling patriotism, respect for the law, and imperial loyalty in children. While expanding children's political horizons, the article narrows those of women. Beyond teaching, women's public political action is deplored as "stump oratory" and the "unsexed confederation" of the "Screaming Sisterhood," that is, the women's suffrage movement. ${ }^{57}$ For Caulfield, and many of her contemporaries, the problem lay not with the principle of women's suffrage but the means of obtaining it. She supported "quiet" and "sober-minded" discussions of the suffrage question convened "in suitable rooms." 58 But the overall picture is clear: girl readers are strongly encouraged to view women's public political engagement as inappropriate. Female politics is sanctioned only to benefit the future citizens of the nation or when kept within strictly female circles behind closed doors.

The politicization of children's education was invariably presented more negatively. Julia Bush and Gillian Sutherland have highlighted contemporary fears about the influence of feminist and suffragist teachers on schoolgirls in elementary and secondary schools. ${ }^{59}$ Such concerns made their way into the Girl's Own Paper in March 1910, two years into the more conservative editorship of Flora Klickmann. "Some Pitfalls of the Modern Teacher" shows examples of teachers sharing their socialist and feminist views with pupils. These include a mathematics mistress who devotes parts of her lessons to drumming up support for women's suffrage, a history teacher giving a socialist interpretation of the Peasants' Revolt, and a 
singing professor who inspired some of his pupils to take part in a women's suffrage procession to Hyde Park. ${ }^{60}$ Although the author hopes such instances were "exceptional cases," similar concerns are evident in previous decades. ${ }^{61}$

In 1889, for example, Punch published the story of a governess who was dismissed from service in a Conservative family for inculcating Gladstonian views in her pupils. Female political awareness is presented as a threat to the "paterfamilias," disrupting the home with "the orations of Home-rulers in home-spun, Tories in tailor-made frocks, Liberals in lace, Conservatives in crinoline, Socialists in short petticoats, and Fenians in frills." ${ }^{62}$ The mocking tone of the article criticizes both schoolgirls' engagement with politics and the politicizing influence of female teachers. Its assumption of girlhood rebellion rather than adherence to paternal political opinion is especially interesting. Elsewhere, girls are again shown to be indoctrinated by women into political views contrary to those of their father. In 1896, a Conservative, Anglican father complained that his daughters were being taught Radical views by the female head teacher of a Lancashire Wesleyan day school. ${ }^{63}$ The religious overtones in his complaint reflect the denominationalism rife in the nineteenth-century education system. In these examples, the importance placed on guarding girls from exposure to certain political ideologies reveals contemporary assumptions about the impressionability of female youth. Interestingly, girls' political socialization appears less problematic than the challenge to patriarchal authority that it represented. This challenge, notably, arises from the actions of politicized female teachers rather than girl pupils. Concerns about girls' politicization thus seem less a matter of principle than of means, with the fundamental question remaining not whether girls should be exposed to politics but how and from whom they should receive their political education.

The politicizing influence of the boys' public school has received considerable scholarly attention. Patrick Joyce suggested that, by teaching boys to govern themselves and 
others, public schools were "machines for making governors." ${ }^{64}$ Jenny Holt further noted that relatively uncontrolled leisure time enabled public schoolboys to take part in subversive and political activities; schools" "rhetorical culture" encouraged participation in political debate. ${ }^{65}$ These narratives are reflected in the Boy's Own Paper in detailed, often comic, accounts of schools' mock parliaments and schoolboys' participation in election agitation, as well as politicized descriptions of public school hierarchies. ${ }^{66}$ Politics could also feature in schoolgirl stories. In contrast to boys' schools, these stories suggest that girls' education discouraged schoolgirl politics. Where politics appears in girls' schools, it is due to schoolgirls' own initiative and is, therefore, more subversive.

One example is the Girl's Own Paper's 1880-81 series “That Aggravating Schoolgirl," by Grace Stebbing. ${ }^{67}$ In one instalment, the high-spirited schoolgirl heroine, Helen, invokes party politics in her power struggle against school authority. Casting her teacher as a "Conservative" - thus opposing Helen, who is a Liberal like her father-she uses "free trade" principles to overturn a decision to prevent schoolgirls having sweets. ${ }^{68}$ Helen's use of politics in such a dispute might seem trivial, but it is important that such politicized language is attributed to a schoolgirl at all. Despite her seemingly negative epithet, the “aggravating schoolgirl” becomes a figure for girl readers' admiration by emerging triumphant in her struggle against the oppressive authority of her teachers. Schoolgirls' political precocity could be something to be celebrated.

Formal schooling was only part of the picture. Girls' political education also took place outside the school, including through the periodical press. The politically educative potential of girls' periodicals is most explicit in several non-fiction articles in the Girl's Own Paper. In 1881, the four-part series "The Government of Our Country" provided a detailed account of the party political structure and the electoral and legislative processes. ${ }^{69}$ The author, Hon. Mrs. Armytage, was the daughter of a politician and personally interested in 
affairs of the state; her other writings included Old Court Customs and Modern Court Rule, published in 1883. This helps explain why she urged girls to educate themselves about the structures of government. Recognizing that the subject matter was unusual for the periodical, she opened the first article in the series with the question: "Will this title frighten my readers, and the page be closed for fear of its exceeding dryness?"70 From the outset, the girl reader is assumed to be unfamiliar with, or uninterested in, politics.

Such sustained engagement with governmental and parliamentary themes is not seen again in the Girl's Own Paper until the following decade, with the publication of a series entitled "Politics for Girls" between 1895 and 1896. In contrast to the earlier series, the author, Frederick Ryland, addresses the question of female political participation more closely. He provides examples of women's work in local government and criticizes the "conventional opinion that women ought to know nothing about politics."71 Appealing directly to the future political role of the periodical's female readers, Ryland writes, "It seems probable that before the girls who read this page grow into full womanhood, the Parliamentary franchise...will be given to women in the United Kingdom."72 This was a bold claim for a periodical that typically advocated a more conservative form of femininity. It exemplifies the "variety of competing voices" in periodical literature of the era, where multiple and contradictory representations of girlhood could coexist within a single issue. ${ }^{73}$ The timing of the series is significant. The 1890s saw increased support for women's suffrage in the House of Commons, with bills debated in 1892 and $1897 .{ }^{74}$ This suggests the influence of the broader political context on periodical content. While Rodgers has rightly challenged monolithic readings of the Girl's Own Paper's supposed conservatism, its more varied construction of girlhood clearly went beyond the discussions of employment and education she identified, also encompassing female political participation. ${ }^{75}$ 
Along with these more focused political pieces, other articles in the Girl's Own Paper sometimes contained throwaway political references. Phrases such as "I changed schools as a place-hunter changes his politics" and "With political parties I've nothing to do, The Whig I support and Conservative, too" appeared in fiction and poetry pieces. ${ }^{76}$ Frederick Ryland, the author of the "Politics for Girls" series, had written earlier on "Logic for Girls." Here, he uses political examples with terms and figures, such as MPs, Committees, Home Rulers, Unionists, and McCarthy, without further explanation. ${ }^{77}$ Similarly, in an autobiographical article published the same year, a female author uses the political labels "socialist," "woman's rights advocate," and "Primrose dame" casually, without providing definitions. ${ }^{78}$ How far readers understood such terms is, of course, impossible to determine. What is important, however, is that authors did not feel the need to censor such political content from their articles. By leaving these terms unexplained, they assume a level of political knowledge from their readers.

Readers' contributions to periodicals, though complicated by editorial selection, are a valuable source for how girls engaged more directly with political questions. Highlighting the conflicting narratives within periodical literature, Kirsten Drotner notes that correspondence columns often reveal the "most glaring contradictions."79 Indeed, it is here that the Girl's Own Paper's apolitical claims appear most unstable. The periodical responded on multiple occasions to questions about the origins and definitions of party political terms, including Whig, Tory, Liberal, Conservative, and Radical.$^{80}$ Readers asked these questions so frequently that "The Inquiring Mind" was advised on January 3, 1885, to "read what we have recently said on this question." ${ }^{, 81}$ Correspondence pages thus provided a mechanism for readers to expand their political understanding.

The combination of political and domestic questions from the same reader is particularly interesting. In two examples, explanations of party labels and the length of 
parliamentary terms were followed by advice on velvet and geraniums. ${ }^{82}$ These readers engaged with politics with relative ease, much as they would any other topic. In their responses, editors again sometimes assumed prior political knowledge from their readers. In July 1884, "Snowdrop" received the following response: "As to the political views originally held by the present Premier, he first sat as a Conservative, and everyone knows what he is now." 83 Admittedly, expecting readers to know that Gladstone was the current Liberal Prime Minister sets the bar low. Elsewhere, though, answers refer to other prominent nineteenthcentury politicians_-including Lords Grey, Melbourne, Russell, Palmerston, Salisbury, and Beaconsfield and Sir Robert Peel—as well as the Primrose League. ${ }^{84}$ Responses could even signpost readers to other sources of political information; readers of the Girl's Own Paper and Boy's Own Paper were informed where they might buy copies of government legislation. ${ }^{85}$

Correspondence columns also offered readers a rare opportunity to express party political allegiances. As Siân Pooley's study of children's contributions to the English provincial press between 1876 and 1914 demonstrates, although politics and religion were absent from the children's columns, children could engage with these issues in their letters. ${ }^{86}$ These political correspondences were not published, but in the Girl's Own Paper, correspondence pages occasionally allowed readers to display their partisan views. For example, in 1880, correspondents adopted pseudonyms such as "Staunch Conservative" and "Youthful Liberal." 87 Parallels can be drawn with the Boy's Own Paper here, where the following year one correspondent used the alias "Young Liberal." ${ }^{88}$ Chris Philo and Fiona Smith note the "quasi-political" nature of letters written by children to Eleanor Roosevelt during the Great Depression, demonstrating how this contributed to the formation of their political identities. ${ }^{89}$ This provides a helpful framework for analyzing juvenile writing about political matters within the public forum of the late nineteenth-century periodical 
correspondence page. The correspondence page, too, may have developed contributors' understanding of their own political subjectivities. Political engagement through correspondence remained, however, tightly controlled. Initially, boys' periodicals were less willing to respond to political questions, which suggests that influencing the political views of the future male electorate was particularly controversial. From the late 1880s, the Girl's Own Paper and Boy's Own Paper, both published by the Religious Tract Society, consciously directed their correspondence columns away from political matters. As we have seen, the Girl's Own Paper continued to publish politically educative content after this date, but readers' more direct political interaction was curtailed. Given that both periodicals made this change simultaneously, girls' and boys' political engagement seem to have required the same close control.

Elsewhere in the periodicals, girls' political expression was presented as separate from that of boys. Fashion was one way in which girl readers were encouraged to engage with political and national events. While dress fell within conventional feminine boundaries, the appearance of political themes within regular features such as the Girl's Own Paper's "How a Girl Should Dress" and the Girl's Realm's "Fashions for Girls" disrupted the gender conventions of these periodicals. Readers were informed how to dress appropriately to mark Queen Victoria's Golden and Diamond Jubilees, as well as her death, and to support troops in the Boer War. ${ }^{90}$ This was a means for girls to publicly express their patriotic loyalty to the monarch and empire, but fashion could also be deployed for more partisan purposes. To coincide with the 1886 general election, the Girl's Own Paper included advice on "political bonnets" in various party colors, including the "primrose bonnet" of "yellow and very pale primroses" versus the "opposing headgear...of blue and green tulle." ${ }^{91}$ Here, the periodical aligned itself with a long history of women participating in election rallies and political demonstrations wearing the colors of their party. ${ }^{92}$ Girl readers were thus incorporated within 
this adult female political culture. Within these strictly gendered terms, the periodical sanctioned girls' public support for political parties.

Studies of political socialization have long emphasized the significance of family influence on developing children's understanding of politics. ${ }^{93}$ In the nineteenth-century context, Carol Dyhouse argues that the "family is the primary and most powerful agency of socialisation." 94 Although rightly suggesting that girls could develop feminist identities at home, she framed this exclusively as a reaction against the restrictions of domestic life. ${ }^{95} \mathrm{By}$ contrast, more recent analyses have suggested how families could deliberately inculcate political values in children. Sarah Richardson demonstrates how children's political education was "encouraged by conversation, reading and debate," drawing on a longer middle-class and elite pedagogical tradition of "familiar conversation." 96 But depictions of family politics within the Girl's Own Paper were often more conservative. Male relatives at times are shown to exclude girls from political discussions. In one example, the young girl Eunice resents her father's "discussing politics with other gentlemen, forgetting all about the poor, shy little daughter, who languished in a corner." 97 Here, it is perhaps Eunice's age rather than gender that excludes her from the conversation. Notably, she resents the lack of paternal attention rather than her exclusion from political discussion. Nevertheless, this chapter of the serial story implies that political debate is adult and male, rather than youthful or female. In contrast to the periodical's more overt encouragement of girls' engagement with politics, throwaway comments embedded within periodical fiction often fall back on stereotypical narratives of politics as a male domain.

In other articles, the family provides a sanctioned but limited platform for girls' political action. Girls' engagement with politics keeps elderly relatives informed of parliamentary affairs, provides intelligent company for men, and supports future sons' education for public life, but in these examples girls' personal interest in politics is 
downplayed. ${ }^{98}$ For example, Rosa, in her early twenties, painstakingly reads the political news of the day to her elderly aunts, despite her own lack of interest, "as she was no politician." 99 This was not always the case. In December 1885, the Girl's Own Paper depicted an adolescent girl incorporating political speeches from newspapers into her creative writing, suggesting how girls might use political discourse as a template in their own compositions. ${ }^{100}$ The periodical not only implied that girls might have access to parliamentary reports in the press but also that they could appropriate political discourse in their own recreation within the home.

As with imperial play, political and patriotic recreations were sometimes encouraged by early twentieth-century girls' periodicals. To mark the coronation of Edward VII, readers of the Girl's Own Paper were urged to deploy their needlework skills for patriotic ends. “Coronation Designs for Fancy Nicknacks" provides readers with patterns for a "Rose of England pincushion," a "crown needlecase," and a "coronation bag." 101 The article indicates how a feminine pastime could be directed towards a celebration of the nation and monarchy. Suggestions for readers' play in girls' periodicals could also extend into the realm of parliamentary politics. In January 1902, the Girl's Realm proposed several famous figures for readers to recreate as waxworks, including Joseph Chamberlain, Secretary of State for the Colonies. "Chamberlain only needs an eyeglass, and an orchid in his buttonhole, to show whom he is meant for," the article advised. ${ }^{102}$ Girl readers were expected to recognize and replicate this political caricature, but as with the Paul Kruger hand shadow from the previous year, as the title suggests, this political play is again directed outwards as "a Christmas entertainment." Girls' political play seemed to be easier to justify when performed to a presumably adult audience. In the suggested dialogue, moreover, Chamberlain discusses his hobby of orchid growing rather than his political career. ${ }^{103}$ Even when mimicking a Member of Parliament, appropriating party political sentiment was off limits for girls. 
As we have seen, debates about the politicizing influence of the school environment for girls were widespread in the late nineteenth- and early twentieth-century press. Implicit in these narratives was an assumption that girls' exposure to political ideologies-however lamentable it might be-was unavoidable. Objections thus focused less on the principle of girls' political socialization than on the means. The Girl's Own Paper engaged with the debate in conflicting ways. Young female teachers had a duty to socialize the next generation into citizenship, but girls could be vulnerable to the socialist and feminist impulses of their educators. Elsewhere, the periodical celebrated, at least in fiction, schoolgirls' appropriation of political discourse within their peer cultures. The home, too, was presented as both enabling and limiting girls' political engagement. Political girlhood therefore took various forms. More importantly, the girls' periodical itself could act as a site for girls' political education. Despite conventional understandings of its conservatism, the Girl's Own Paper on occasion exposed its readers to parliamentary political themes. Several non-fiction pieces informed readers about the mechanisms of government, whereas incidental political references could make their way into unrelated periodical content. The latter suggests that editors and authors saw no need to censor political content or contextualize it; the girl reader was assumed to have a prior level of political knowledge. In correspondence columns, readers at times demonstrated a desire to expand this knowledge. Here, the periodical provided a rare platform for readers' expression of party political opinions.

\section{Conclusion}

This essay has argued that the girls' periodical press made an important contribution to late nineteenth- and early twentieth-century ideas of political girlhood. The "political girl" had its place alongside other literary representations of the "new girl." Periodicals depicted girls not only as breaking new ground in education, the workplace, and domestic relations but also in the cultivation and expression of their imperial and political identities. It has not been my 
intention to deny the very real restrictions girls experienced in every sphere of their lives well into the twentieth century, nor am I suggesting that the Girl's Own Paper or the Girl's Realm were bastions of feminism suffused with political content. However, important instances where empire and politics are treated in both periodicals demonstrate that their representations of fin de siècle girlhoods were more varied and complex than has previously been acknowledged. Uncovering these moments that jar with the dominant tone of the publications can nuance our understanding of the girls' periodical press and received historiographical assumptions of girlhood apoliticism.

Parliamentary political themes were most evident in the Girl's Own Paper. The girl reader's political engagement through the periodical was at once educative, incidental, and interactive. Explicitly informative non-fiction pieces exposed readers to detailed knowledge about the political system. Throwaway references to politics elsewhere in the periodical assumed that readers already had a level of political understanding. Correspondence pages enabled readers to appropriate these political narratives themselves, either to display their partisan allegiances or ask for more information on political topics. By contrast, the Girl's Realm engaged more with the concept of imperial girlhood, with the Second Boer War particularly influencing its content. Imperial heroines and overseas escapades were, however, only part of this picture. Moments of more direct interaction between the reader and periodical instead brought the empire closer to home. Through the periodical's celebration of girls' literary contributions and play, imperialism entered the domestic sphere. As such, empire was shown to be a more immediate and relatable part of girls' daily lives.

Gender and age were key determinants of the boundaries of girls' autonomous appropriation of political and imperial narratives. The periodicals' suggestions for girls' practical engagement with politics and empire often remained within feminine limits; sewing, fashion, writing, and domestic play could become sites for patriotic and political expression. 
The appearance of political discourse within these conventionally feminine areas destabilized the periodicals' gendered conventions. Within fiction pieces, girls who deployed politicized language and action were presented as archetypal "new girls": confident and assertive leaders unafraid to disrupt feminine convention or adult authority. They were, however, often younger than other literary figures fitting this model. In terms of age, preadolescence thus offered girls the greatest freedom to express their political and imperial subjectivities. Through imaginary and structured play, young girls could experiment with imperial and political agency in a way that was acceptable to adults. This did not, however, diminish girls' sense of their political selves. By appropriating and contributing to narratives of political girlhood and public life, girls staked their claim as imperial and political subjects.

University of Cambridge

\footnotetext{
${ }^{1}$ Marshall, “Queen Mab,” 242.

${ }^{2}$ Ibid., 239.

${ }^{3}$ Mitchell, New Girl, 3.

${ }^{4}$ Watson, "Girls Then and Now," 420.

${ }^{5}$ Ibid.
}

${ }^{6}$ See Drotner, English Children and Their Magazines, Reynolds, Girls Only?, and Moruzi, Constructing Girlhood, for a discussion of girls' periodicals and the girl reader. In "Feminine Bravery" and chapter 7 of Constructing Girlhood, Moruzi argues girl readers engaged with contemporary events such as the Boer War and women's suffrage. For other work on imperial girlhood in the periodical press, see Smith, Empire in British Girls' Literature, and Moruzi and Smith, eds., Colonial Girlhood.

${ }^{7}$ Kallio and Häkli, “Tracing Children's Politics," 107; Bosco, "Play, Work or Activism?” 
${ }^{8}$ Corsaro, Sociology of Childhood, 18.

${ }^{9}$ Galbraith, Reading Lives, 1.

${ }^{10}$ Beetham, A Magazine of Her Own?, 11-13.

${ }^{11}$ Mitchell, New Girl, 113-15.

${ }^{12}$ Rodgers, Adolescent Girlhood, 210.

${ }^{13}$ Moruzi, Constructing Girlhood; Smith, Empire in British Girls' Literature; Moruzi and Smith, eds., Colonial Girlhood. For imperial boyhood, see Dunae, "Boys' Literature and the Idea of Empire"; Bristow, Empire Boys.

${ }^{14}$ Moruzi, "Feminine Bravery," 243.

${ }^{15}$ Corkran, "Chat with the Girl of the Period," 362.

${ }^{16}$ V. M. A., "Chronicle of the Schools," 545.

17 "Socks for Our Soldiers in South Africa," 431; "“Comforts' for Our Soldiers in South Africa," 516.

${ }^{18}$ Answers to Correspondents," (October 6, 1900): 16; Ibid. (October 13, 1900): 32; Flora, “Children's Own Corner,” (April 1900): 638.

19 “Thousand Pounds to Spare," 480.

${ }^{20}$ Moruzi, "Feminine Bravery," 248.

21 “Answers to Correspondents," (November 17, 1900): 112; Ibid. (April 13, 1901): 448; Ibid. (September 7, 1901): 784.

${ }^{22}$ Corkran, "The Children's Own Corner," 330.

${ }^{23}$ For the celebration of Queen Victoria in girls' periodicals see Rodgers, Adolescent Girlhood, 50-3.

24 “Answers to Correspondents," (April 26, 1902): 480.

${ }^{25}$ Ibid.

26 “Answers to Correspondents," (October 20, 1906): 48; “The Erinna Club," 125. 
27 "Result of the Prize Competitions," 894.

28 'Flora', “The Children's Own Corner," (September 1900): 1112; Ibid. (October 1900): 1206.

${ }^{29}$ Rodgers, “Competing Girlhoods,” 277. See Smith, Empire in British Girls' Literature, 3845, for a discussion of how the Girl's Own Paper aimed to create an "international community of girl readers." For other examples of how the Girl's Own Paper and the Girl's Realm fostered an "international community of girls," see Dawson, "Our Girls in the Family of Nations."

${ }^{30}$ Corkran, “Literary Page,” 751.

31 “Result of Kipling Literary Page Essay for May,” 1058.

${ }^{32}$ Corkran, “The Girl's Realm Reading Union: On Some Essays on 'The Expansion of England,," 650

${ }^{33}$ Ibid.

${ }^{34}$ See Graham Dawson's Soldier Heroes for the role of boyhood play in imagining imperial and military masculinities.

${ }^{35}$ Jackson, "Our Neighbour Over the Way," 965-72; Patch, "How De Wet was Captured," 942-7.

${ }^{36}$ Whitby, "The Land Grabbers," 258.

${ }^{37}$ Ibid., 257-8.

${ }^{38}$ Rodgers, "Competing Girlhoods,” 279.

${ }^{39}$ Devant, "Hand Shadows," 276.

40 “Toying with a Typewriter," 580-1.

41 “Advertisements," iii.

${ }^{42}$ Ibid.

43 "Round About the Shops," iv. 
${ }^{44}$ Wigram, “A Daughter of the Empire,” 741.

45 "Patriotism in Doll Land," 1188.

${ }^{46}$ Ibid., 1190. In "Our Girls in the Family of Nations," Dawson cites “A Daughter of the Empire" and "Patriotism in Doll Land" as examples of girls' enthusiasm for empire but does not draw out this broader theme of girls' imperial play.

${ }^{47}$ Barham, “The Delights of Fancy Dress,” 247; Pearl Humphry, “Ten New Fancy Dresses Designed Specially for 'The Girl's Realm'," 144-5.

${ }^{48}$ Gleadle, "Playing at Soldiers," 336.

${ }^{49}$ Mitchell, New Girl, 3.

${ }^{50}$ Vincent, Literacy and Popular Culture in England, 236; Yeandle, Citizenship, Nation, Empire, 1-3.

${ }^{51}$ Shirreff, "Original Articles: The Study of History in Schools, III,” 115.

${ }^{52}$ Jordan, “"Making Good Wives and Mothers'?," 439-40.

53 "National Union for Improving the Education of Women of All Classes," 54-6.

54 “The Teaching of History," The Times, January 13, 1912, 6; "Women Teachers and the Vote," The Times, April 8, 1912, 8.

55 “Learning to Read," The Times, August 28, 1873, 4.

${ }^{56}$ Caulfield, "Some Types of Girlhood," (October 4, 1890): 4-5; Ibid. (December 27, 1890):

196-7; Ibid. (January 17, 1891): 244-6. 'Political girlhood' features in the December 1890 issue.

${ }^{57}$ Ibid. (December 27, 1890): 197.

58 Ibid.

${ }^{59}$ Bush, Women Against the Vote, 232; Sutherland, In Search of the New Woman, 128.

60 "Some Pitfalls of the Modern Teacher," 359-60.

${ }^{61}$ Ibid., 360. 
62 "Politics for School-Girls," Punch, February 23, 1889, 87.

63 "Politics in Schools," Cheshire Observer, June 20, 1896, 5.

${ }^{64}$ Joyce, The State of Freedom, 229.

${ }^{65}$ Holt, Public School Literature, 30-1.

${ }^{66}$ Baines Reed, “The Fifth Form at St. Dominic's,” 153; Baines Reed, “The Willoughby

Captains," 113; “Our 'General Election',” 281.

${ }^{67}$ This series was later published as a novel in 1885 .

68 “That Aggravating School Girl,” 334-5.

${ }^{69}$ The Hon Mrs Armytage, “The Government of Our Country,” (January 1, 1881): 214-15;

Ibid. (April 2, 1881): 419-20; Ibid. (May 21, 1881): 531-2; Ibid. (July 9, 1881): 651-2.

${ }^{70}$ Ibid., (January 1, 1881): 214.

${ }^{71}$ Ryland, "Politics for Girls," 86.

72 Ibid.

${ }^{73}$ Fraser, Johnston, and Green, Gender and the Victorian Periodical, 1.

${ }^{74}$ Pugh, March of the Women, 79-80.

${ }^{75}$ Rodgers, Adolescent Girlhood, 27.

76 “Memories of Childhood," 28; "Varieties," 80.

${ }^{77}$ Ryland, "Logic for Girls,” 195-7.

78 “My Hyacinths," 349-50.

${ }^{79}$ Drotner, English Children and Their Magazines, 157.

80 “Answers to Correspondents," (May 22, 1880): 335; Ibid. (August 21, 1880): 544; Ibid.

(November 22, 1884): 127.

81 “Correspondence Awaiting the Editor," 224.

82 “Answers to Correspondents,” (August 21, 1880): 544; Ibid. (October 2, 1880): 15.

${ }^{83}$ Ibid. (July 12, 1884): 655. 
${ }^{84}$ Ibid. (February 17, 1883): 319; Ibid. (December 14, 1889): 175.

${ }^{85}$ Ibid. (July 18, 1903): 672; “Correspondence,” (August 24, 1889): 751.

${ }^{86}$ Pooley, "Children's Writing and the Popular Press," 81.

87 “Answers to Correspondents,” (August 21, 1880): 544; Ibid. (September 25, 1880): 624.

88 “Correspondence," 32.

${ }^{89}$ Philo and Smith, "Guest Editorial," 103.

${ }^{90}$ A Lady Dressmaker, “Dress: In Season and in Reason,” (April 23, 1887): 472-3; 'The Lady Dressmaker,' “To-day’s Apparel,” (April 24, 1897): 472-3; Ibid. (May 29, 1897): 553; Ibid. (June 26, 1897): 617; "How a Girl Should Dress," 120; Whitley, "Fashions for Girls," 636. ${ }^{91}$ A Lady Dressmaker, “Dress: In Season and in Reason,” (July 31, 1886): 698.

${ }^{92}$ Rogers, Women and the People, 18.

${ }^{93}$ For early works on this subject, see Hyman, Political Socialization, 51; Dawson and Prewitt, Political Socialization, 105.

${ }^{94}$ Dyhouse, Girls Growing Up, 3.

${ }^{95}$ Dyhouse, Feminism and the Family.

${ }^{96}$ Richardson, The Political Worlds of Women, 22; for the tradition of "familiar conversation," see Cohen, "The Pedagogy of Conversation in the Home."

${ }^{97}$ De Horne Vaizey, “More About Peggy,” 237.

${ }^{98}$ Silke, "Rainy Days,” 233; “A Cage-Making Wife," 423; King, "The Four Periods,” 124.

${ }^{99}$ Silke, “Rainy Days,” 233.

${ }^{100}$ Hope, "Winter Evenings at Home," 151.

${ }^{101}$ Clifford, "Coronation Designs for Fancy Nicknacks," 500-2.

102 Sharp, "Waxworks: Hints for a Christmas Entertainment," 252.

${ }^{103}$ Ibid., 254. 


\section{BIBLIOGRAPHY}

“Advertisements." Girl's Realm 2 (March 1900): iii.

“Answers to Correspondents.” Girl's Own Paper 1 (May 22, 1880): 335-36.

“Answers to Correspondents.” Girl's Own Paper 1 (August 21, 1880): 543-44.

“Answers to Correspondents." Girl's Own Paper 1 (September 25, 1880): 623-24.

“Answers to Correspondents.” Girl's Own Paper 2 (October 2, 1880): 14-15.

“Answers to Correspondents." Girl's Own Paper 4 (February 17, 1883): 318-20.

“Answers to Correspondents.” Girl's Own Paper 5 (July 12, 1884): 655-6.

“Answers to Correspondents.” Girl's Own Paper 6 (November 22, 1884): 127-8.

“Answers to Correspondents." Girl's Own Paper 11 (December 14, 1889): 175.

“Answers to Correspondents.” Girl's Own Paper 22 (October 6, 1900): 16.

"Answers to Correspondents." Girl's Own Paper 22 (October 13, 1900): 32.

“Answers to Correspondents." Girl's Own Paper 22 (November 17, 1900): 112.

“Answers to Correspondents.” Girl's Own Paper 22 (April 13, 1901): 448.

“Answers to Correspondents.” Girl's Own Paper 22 (September 7, 1901): 784.

“Answers to Correspondents." Girl's Own Paper 23 (April 26, 1902): 480.

“Answers to Correspondents." Girl's Own Paper 24 (July 18, 1903): 672.

“Answers to Correspondents.” Girl's Own Paper 28 (October 20, 1906): 48.

Armytage, Hon. Mrs. “The Government of Our Country.” Girl's Own Paper 2 (January 1, 1881): 214-15.

_. "The Government of Our Country." Girl's Own Paper 2 (April 2, 1881): 419-20.

__. "The Government of Our Country." Girl's Own Paper 2 (May 21, 1881): 531-2. . "The Government of Our Country." Girl's Own Paper 2 (July 9, 1881): 651-2. 
Barham, Beatrice. “The Delights of Fancy Dress.” The Girl's Realm 3 (January 1901): 24553.

Beetham, Margaret. A Magazine of Her Own?: Domesticity and Desire in the Woman's Magazine, 1800-1914. London: Routledge, 1996.

Bosco, Fernando J. "Play, Work or Activism? Broadening the Connections between Political and Children's Geographies.” Children's Geographies 8, no. 4 (2010): 381-90.

Bristow, Joseph. Empire Boys: Adventures in a Man's World. London: Harper Collins, 1990.

Bush, Julia. Women Against the Vote: Female Anti-Suffragism in Britain. Oxford: Oxford University Press, 2007.

“A Cage-Making Wife.” Girl's Own Paper 7 (April 3, 1886): 423.

Caulfield, Sophia F. A. "Some Types of Girlhood, or, Our Juvenile Spinsters." Girl's Own Paper 12 (October 4, 1890): 4-5.

_. "Some Types of Girlhood, or, Our Juvenile Spinsters." Girl's Own Paper 12 (December 27, 1890): 196-7.

—. "Some Types of Girlhood, or, Our Juvenile Spinsters." Girl's Own Paper 12 (January 17, 1891): 244-6.

Clifford, Leirion. “Coronation Designs for Fancy Nicknacks.” Girl's Own Paper 23 (May 10, 1902): 500-2.

Cohen, Michèle. “The Pedagogy of Conversation in the Home: 'Familiar Conversation' as a Pedagogical Tool in Eighteenth and Nineteenth-Century England." Oxford Review of Education 41, no. 4 (2015): 447-63.

“Comforts' for Our Soldiers in South Africa." The Girl's Realm 2 (March 1900): 516.

Corkran, Alice. “Literary Page.” The Girl's Realm 1 (May 1899): 751.

- "Chat with the Girl of the Period." The Girl's Realm 2 (January 1900): 362.

. “The Children's Own Corner.” The Girl's Realm 3 (January 1901): 330. 
_. "The Girl's Realm Reading Union: On Some Essays on 'The Expansion of England'." The Girl's Realm 3 (May 1901): 650-1.

“Correspondence.” Boy’s Own Paper 4 (October 8, 1881): 32.

“Correspondence.” Boy’s Own Paper 11 (August 24, 1889): 751.

"Correspondence Awaiting the Editor." Girl's Own Paper 6 (January 3, 1885): 223-4.

Corsaro, William A. The Sociology of Childhood. 2nd ed. London: Pine Forge Press, 2005.

Dawson, Graham. Soldier Heroes: British Adventure, Empire and the Imagining of Masculinities. London: Routledge, 1994.

Dawson, Janis. "Our Girls in the Family of Nations: Girls' Culture and Empire in Victorian Girls' Magazines.” In Internationalism in Children's Series, edited by Karen SandsO’Connor and Marietta Frank, 38-55. Basingstoke: Palgrave Macmillan, 2014.

Dawson, Richard E. and Kenneth Prewitt. Political Socialization. Boston: Little, Brown, 1969.

De Horne Vaizey, Mrs. G. "More About Peggy." Girl's Own Paper 21 (January 13, 1900): 236-9.

Devant, David. "Hand Shadows - How a Girl May Give a Charming Drawing-Room Entertainment." The Girl's Realm 3 (January 1901): 273-6.

Drotner, Kirsten. English Children and Their Magazines, 1751-1945. New Haven: Yale University Press, 1988.

Dunae, Patrick A. "Boys' Literature and the Idea of Empire, 1870-1914.” Victorian Studies 24, no. 1 (1980): 105-21.

Dyhouse, Carol. Girls Growing Up in Late Victorian and Edwardian England. London: Routledge \& Kegan Paul, 1981.

- Feminism and the Family in England, 1880-1939. Oxford: Basil Blackwell, 1989. “The Erinna Club.” Girl's Own Paper 29 (November 25, 1905): 124-6. 
Flora. “The Children's Own Corner." The Girl's Realm 2 (April 1900): 638.

__. "The Children's Own Corner.” The Girl's Realm 2 (September 1900): 1112.

__. "The Children's Own Corner.” The Girl's Realm 2 (October 1900): 1206.

Fraser, Hilary, Judith Johnston, and Stephanie Green. Gender and the Victorian Periodical. Cambridge: Cambridge University Press, 2003.

Galbraith, Gretchen. Reading Lives: Reconstructing Childhood, Books, and Schools in Britain, 1870-1920. Basingstoke: Macmillan, 1997.

Gleadle, Kathryn. "Playing at Soldiers: British Loyalism and Juvenile Identities during the Napoleonic Wars.” Journal of Eighteenth-Century Studies 38, no. 3 (2015): 335-48. Holt, Jenny. Public School Literature, Civic Education and the Politics of Male Adolescence. Aldershot: Ashgate, 2008.

Hope, Dora. "Winter Evenings at Home: Stay-At-Home Girls.” Girl's Own Paper 7 (December 5, 1885): 150-1.

“How a Girl Should Dress.” Girl’s Own Paper 22 (November 24, 1900): 120.

Hyman, Herbert H. Political Socialization: A Study in the Psychology of Political Behavior. New York: Free Press, 1959.

Jackson, Alice. “Our Neighbour Over the Way.” The Girl's Realm 2 (August 1900): 965-72. Jordan, Ellen. “'Making Good Wives and Mothers'?: The Transformation of Middle-Class Girls’ Education in Nineteenth-Century Britain.” History of Education Quarterly 31, no. 4 (1991): 439-62.

Joyce, Patrick. The State of Freedom: A Social History of the British State since 1800. Cambridge: Cambridge University Press, 2013.

Kallio, Kirsi P. and Jouni Häkli. “Tracing Children’s Politics.” Political Geography 30 no. 2 (2011): 99-109.

King, Alice. "The Four Periods.” Girl's Own Paper 3 (November 19, 1881): 123-4. 
A Lady Dressmaker. “Dress: In Season and In Reason.” Girl's Own Paper 7 (July 31, 1886): 696-8.

—. "Dress: In Season and in Reason," Girl's Own Paper 8 (April 23, 1887): 472-5.

'The Lady Dressmaker.' “To-day’s Apparel.” Girl's Own Paper 18 (April 24, 1897): 472-4.

—_. “To-day's Apparel.” Girl's Own Paper 18 (May 29, 1897): 552-4.

—. “To-day's Apparel.” Girl's Own Paper, 18 (June 26, 1897): 616-18.

"Learning to Read." The Times, August 28, 1873, 4.

Marshall, Emma. “Queen Mab.” Girl’s Realm 1 (January 1899): 239-47.

"Memories of Childhood." Girl's Own Paper 18 (October 10, 1896): 28.

Mitchell, Sally. The New Girl: Girls' Culture in England, 1880-1915. New York: Columbia University Press, 1995.

Moruzi, Kristine. “Feminine Bravery: The Girls' Realm (1898-1915) and the Second Boer War." Children's Literature Association Quarterly 34, no. 3 (2009): 241-54.

- Constructing Girlhood through the Periodical Press, 1850-1915. Aldershot:

Ashgate, 2012.

Moruzi, Kristine and Michelle J. Smith. eds. Colonial Girlhood in Literature, Culture and History, 1840-1950. Basingstoke: Palgrave Macmillan, 2014.

“My Hyacinths." Girl’s Own Paper 14 (February 25, 1893): 349-50.

"National Union for Improving the Education of Women of All Classes." Journal of the Women's Education Union 40 (April 15, 1876): 54-6.

“Our 'General Election'.” Boy’s Own Paper 12 (February 1, 1890): 281.

Patch. "How De Wet was Captured.” The Girl's Realm 3 (September 1901): 942-7.

“Patriotism in Doll Land." The Girl's Realm 2 (October 1900): 1188-90.

Pearl Humphry, H. “Ten New Fancy Dresses Designed Specially for 'The Girl's Realm'.” The Girl's Realm 10 (December 1907): 140-5. 
Philo, Chris and Fiona M. Smith. "Guest Editorial: Political Geographies of Children and Young People.” Space and Polity 7, no. 2 (2003): 99-115.

“Politics for School-Girls." Punch, February 23, 1889, 87.

"Politics in Schools." Cheshire Observer, June 20, 1896, 5.

Pooley, Siân. "Children’s Writing and the Popular Press in England 1876-1914.” History

Workshop Journal 80, no. 1 (2015): 75-98.

Pugh, Martin. The March of the Women: A Revisionist Analysis of the Campaign for

Women's Suffrage, 1866-1914. Oxford: Oxford University Press, 2002.

Reed, Talbot Baines. “The Fifth Form at St. Dominic's: A Public School Story.” Boy's Own Paper 4 (December 3, 1881): 153-5.

__. "The Willoughby Captains.” Boy's Own Paper 6 (November 24, 1883): 113-16.

“Result of Kipling Literary Page Essay for May.” The Girl's Realm 1 (August 1899): 1058.

"Result of the Prize Competitions." The Girl's Realm 2 (July 1900): 894.

Reynolds, Kimberley. Girls Only?: Gender and Popular Children's Fiction in Britain, 18801910. London: Harvester Wheatsheaf, 1990.

Richardson, Sarah. The Political Worlds of Women: Gender and Politics in Nineteenth Century Britain. London: Routledge, 2013.

Rodgers, Beth. "Competing Girlhoods: Competition, Community, and Reader Contribution in The Girl's Own Paper and The Girl's Realm." Victorian Periodicals Review 45, no. 3 (2012): 277-300.

—. Adolescent Girlhood and Literary Culture at the Fin de Siècle: Daughters of Today. Basingstoke: Palgrave Macmillan, 2016.

Rogers, Helen. Women and the People: Authority, Authorship and the Radical Tradition in Nineteenth-Century England. Aldershot: Ashgate, 2000.

"Round About the Shops." The Girl's Realm 2 (March 1900): iv. 
Ryland, Frederick. "Logic for Girls." Girl's Own Paper 15 (December 30, 1893): 195-7. “Politics for Girls.” Girl's Own Paper 17 (November 9, 1895): 86-7.

Sharp, Evelyn. "Waxworks: Hints for a Christmas Entertainment." The Girl's Realm 4 (January 1902): 251-6.

Shirreff, Emily. "Original Articles: The Study of History in Schools, III." Journal of the Women's Education Union 32 (August 15, 1875): 115-18.

Silke, L. C. "Rainy Days.” Girl’s Own Paper 7 (January 9, 1886): 233-5.

Smith, Michelle J. Empire in British Girls' Literature and Culture: Imperial Girls, 18801915. Basingstoke: Palgrave Macmillan, 2011.

“Socks for Our Soldiers in South Africa." The Girl's Realm 2 (February 1900): 431.

“Some Pitfalls of the Modern Teacher." Girl's Own Paper (March 1910): 359-60.

Sutherland, Gillian. In Search of the New Woman: Middle-Class Women and Work in Britain, 1870-1914. Cambridge: Cambridge University Press, 2015.

“The Teaching of History.” The Times, January 13, 1912, 6.

“That Aggravating School Girl.” Girl's Own Paper 2 (February 19, 1881): 334-5.

"The 'Thousand Pounds to Spare' Competition: What the Examiners Have to Say." Girl's Own Paper 22 (April 27, 1901): 479-80.

“Toying with a Typewriter.” Girl’s Own Paper 26 (June 10, 1905): 580-1.

V. M. A. "The Chronicle of the Schools.” The Girl's Realm 2 (March 1900): 545.

"Varieties." Girl's Own Paper 1 (January 31, 1880): 80.

Vincent, David. Literacy and Popular Culture: England, 1750-1914. Cambridge: Cambridge University Press, 1989.

Watson, Lily. “Girls Then and Now.” Girl's Own Paper 24 (April 4, 1903): 420-2.

Whitby, J. E. "The Land Grabbers: A Story for Big Children.” The Girl's Realm 9 (January 1907): $255-8$. 
Whitley, Mrs M. "Fashions for Girls.” The Girl's Realm 2 (April 1900): 636-7.

Wigram, Enid. “A Daughter of the Empire.” The Girl's Realm 2 (June 1900): 741.

"Women Teachers and the Vote." The Times, April 8, 1912, 8.

Yeandle, Peter. Citizenship, Nation, Empire: the Politics of History Teaching in England, 1870-1930. Manchester: Manchester University Press, 2015. 